\title{
Type of Traders' Effect on Risk and Return: The Case of Egyptian Stock Exchange
}

\author{
Aly Saad Mohamed Dawood ${ }^{1} \&$ Khairy El-Giziry ${ }^{2}$ \\ ${ }^{1}$ Faculty of Management, Sadat Academy for Management Sciences, Cairo, Egypt \\ ${ }^{2}$ Faculty of commerce, Cairo University, Giza, Egypt \\ Correspondence: Aly Saad Mohamed Dawood, Faculty of Management, Sadat Academy for Management \\ Sciences, Cairo, Egypt. E-mail: asmdawood@yahoo.com
}

Received: December 11, 2015

Accepted: January 4, 2016

Online Published: January 25, 2016

doi:10.5539/ijef.v8n2p256

URL: http://dx.doi.org/10.5539/ijef.v8n2p256

\begin{abstract}
This research paper aims to estimate the effect of investor categories (Foreigners, Arab, Egyptian institutions and individuals) trading volume, value and number of transactions on capital market returns and volatility.

We depend on data Foreigners, Arabian and Egyptian trading volume, values and number of transaction of buying and selling for institutions and individuals and capital market values for the period from January 1 st 2009 to December 312013.

We used descriptive statistics to identify normal distribution of data. Then, performing lead lag structure approach to obtain the optimum lag for the independent variable which has the maximum correlation with the dependent variable. Next, Garch model utilized to estimate the effect of trading volume, value, number of transactions on capital market return and volatility. Finally, the same model utilized to estimate the effect of investor categories on capital market return and volatility for the six periods starting from January $1^{\text {st }} 2009$ to December 312013 which represents the whole period and five yearly periods for the same period.

We found that institutions are the main source of volatility in the Egyptian stock market. Garch models showed weak effect on volatility for all periods. In the light of this study Foreigners and trading value items are the main source of effect on volatility. Finally, consistent with Chou (1988), the findings of GARCH model indicated that volatility persistence is less than unity which revealed that the Egyptian stock market could absorb shocks across time.
\end{abstract}

Keywords: traders, risk, return, volatility, Egyptian stock exchange

\section{Introduction}

Market volatility affects the incentive to save and to invest. That is the more volatile the asset market holding the average return constant the less the agent will save and hence the less investment will be. But, certain degree of market volatility is unavoidable even desirable as one would like the stock price fluctuation to indicate changing values across economic activities so that resources can be better allocated. Next three figures show the trend trading volume, value and number of transactions across the last five years quarterly were as follows:

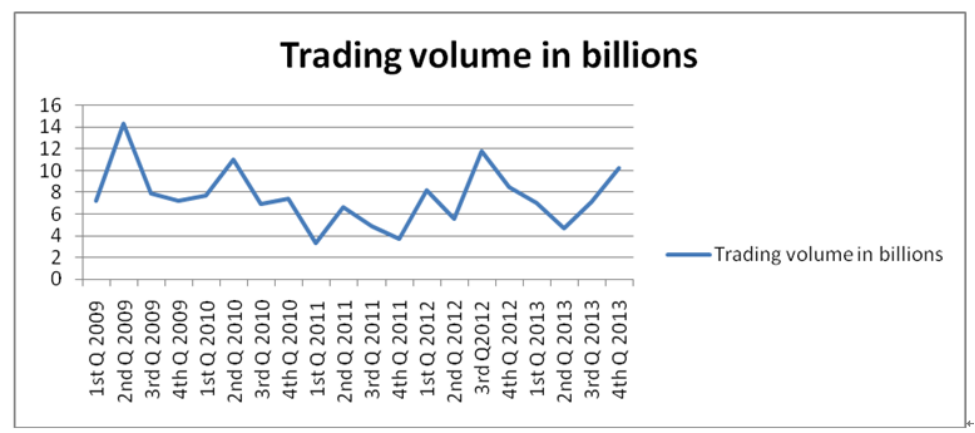

Figure 1. Trading volume in millions 


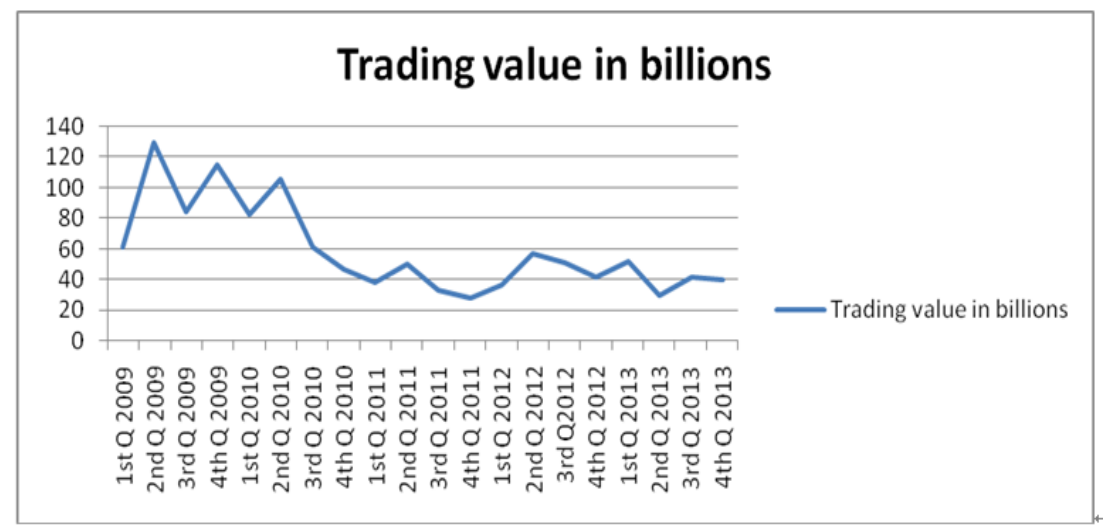

Figure 2. Trading volume in billions

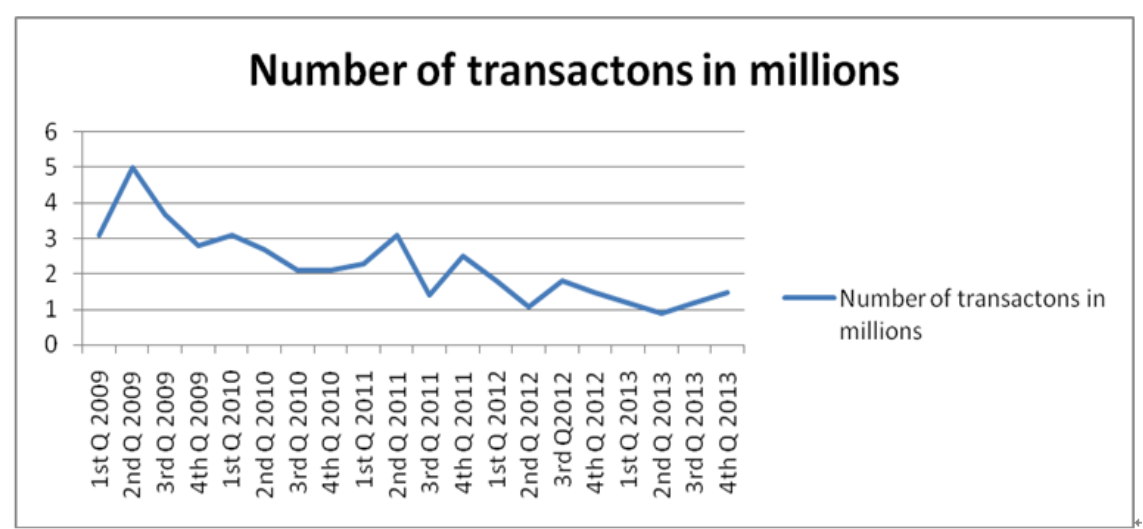

Figure 3. Number of transactions in millions

We could observe from the previous figures strong variance across time for all and at the same time curves were not moving in the same directions especially after 2010 which mean that those variables might vary in their effect on capital market return and volatility across time. The rest of the paper will be organized as follows. Section 2 explain the literature review, section 3 the methodology, section 4 the results of the analysis and section 5 provide the conclusion.

\section{Literature Review}

Tauchen and Pitts (1983) suggest that, in liquid or mature markets, where the number of stocks traders is large, the relationship between trading volume and volatility of price change should be positive. According to Wang (1994) investor heterogeneity and incomplete markets in asset pricing models, trading volume play important role in influencing asset prices. He developed one such "rational expectations" model, linking trading volume to stock price volatility under asymmetric information and found a positive relation between trading volume and absolute changes in stock prices. However informed and uninformed investors behave differently in his model. Huang, Roger D. and Masulis, Ronald W. (2003) analyzed transactions data for financial Times stock Exchange and showed that trade frequency and average trade size effect price volatility for small trade. While large trades have a frequency affects price volatility. Then, Xioo, and Wang (2007) examined the static relationship between stock return and trading and they found a significant positive correlation between them. Girard and Biswas (2007) investigated the relationship between volatility and volume in 22 developed markets and 27 emerging markets which could be attributed to relative inefficiency in those markets. They showed that when volume is decomposed into expected and unexpected components volatility persistence decrease. Again Girard and Omran (2009) showed identical results in the Egyptian stock Exchange. kyrolainen (2009) examined whether day trading is related to volatility of stock prices and found a strong positive time-series relation between the number of day trades by individual investors and intraday volatility among heavily day traded stocks. Li, and Wana (2010) examined the short-run dynamic relation between daily institutional trading and stock price volatility in a retail investor-dominated emerging market and they found a significant negative relation between volatility and 
institutional net trading that was mainly due to the unexpected institutions trading. Tayde and Raq (2011) examined foreign institutional investors whether they exhibited herding and positive feedback trading while investing in the Indian market and they found that foreign institutional investors exhibited herding and positive feedback trading during different phases of the stock market. Bagchi (2012) examined the relationship between volatility index and stock index return by using three parameters stock beta, market to book value of equity and market capitalization for sorting purpose and found that India VIX had a positive and significant relationship with the returns of the value-weighted high-low portfolio sorted on the basis of the above parameters.

Chuang and Susmel (2012) investigated contemporaneous and causal relations between trading volume and stock returns for ten Asian stock market (Hong Kong, Japan, Korea, Singapore, Taiwan, China, Indonesia, Malaysia, Philippines and Thailand) and they found that there were a positive bi-directional causality between stock returns and trading volume in Taiwan and China, and between trading volume and return volatility in Japan, Korea, Singapore and Taiwan. Furthermore, Kaniel et al. (2012) examined information content of trading by individual investor's trades around earning announcements and they found that aggregate individual investor trading predicts abnormal stock return at and after earnings announcement dates and about half of the post earnings announcement abnormal return can be attributed to private information. Also, Ulku and Weber (2013) employed daily data on trading of various investor types and they found that merchant trading had both significant information content and forecasting ability; private funds were positive feedback traders but their trading had limited informational content, foreign investors were positive feedback traders and they also had significant information content. while, Adaoglu and katirciogler (2013) investigated the direction of causality between the monthly stock returns and the monthly net foreign investor flows and existence of feedback trading by foreign investors for the "blue ship" stocks of the Istanbul stock exchange and they found that unidirectional causality running from monthly stock returns to monthly net foreign investor flows detected from the pre-En accession negotiation period accompanied by a negative feedback trading could not be established for the post-Eu accession negotiation period, the relationship in a contemporaneous one rather than a lagged relationship for the latter period. Furthermore, Lan et al. (2014) studied the relationship between price volatility, trading volume by using threshold model, variable decomposition and found that the increasing volume adds to price volatility and opposite to developed markets, unexpected volume had less interpretation power for price volatility than expected volume. Finally, Tomas, Heryan (2014) examined whether the prices volatility of selected financial companies shares differs within the both samples below its average of trading volume and above. They founded no significant relationship between trading volume and stock price volatility.

The literature review showed the following aspects:

- Trade size and frequency influences stock price volatility.

- Institution and individual had a significant effect on stock price volatility.

- There were a relation between trade volume and stock market volatility and when it was decomposed into expected and unexpected volatility decrease.

- There was a relation between positive feedback trading and stock price volatility.

- There were different contemporaneous and causal relations between trading volume and stock returns across countries.

Thus most previous studies concentrate on the relation between trading and stock price or return volatility. While this examines the effect of institutions and individuals for (foreigners, Arab and Egyptians) trading volumes, values and number of transactions on capital market return volatility and its variation across different circumstances. In doing so, the following questions will be addressed:

- $\quad$ To what extent the investor categories Foreigners, Arab, Egyptian institutions and individuals trading volume, value and number of transactions affects the capital market return volatility?

To what extent those effects vary in the last five years?

\section{Data and Methodology}

The research used data related to trading volume, values and number of transaction for buying and selling done by different investor categories institutions and individuals decomposes into Foreigners, Arabian and Egyptian and capital market values on daily basis. These data are collected during the period from January $1^{\text {st }} 2009$ to December 31, 2013, divided into six time series, the first one include the whole period and the rest divided yearly. Variables can be defined as follows:

A. Independent variables: 
Total trading volume which is the number of shares traded in a stock market for a given period, typically for one day divided into:

Trading volume for institution (X1) decomposes into:

Trading volume for Egyptian institutions (X11).

Trading volume for foreign institutions (X12).

Trading volume for Arab institutions(X13).

Trading volume for individuals (X2) decomposes into:

Trading volume for Egyptian individuals(X21).

Trading volume for foreign individuals(X22).

Trading volume for Arab individuals(X23).

Total trading value which is the number of shares traded multiply by its close price (market price) in a stock market for a given period, typically for one day divided into:

Trading value for institutions (X3) decomposes into.

Trading value for Egyptian institutions(X31).

Trading value for foreign institutions(X32).

Trading value for Arab institutions(X33).

Trading value for individuals (X4) decomposes into.

Trading value for Egyptian individuals(X41).

Trading value for foreign individuals(X42).

Trading value for Arab individuals(X43).

Total number of transactions which is the sum of buys and sell transactions on shares in a stock market for a given period, typically for one day divided into:

Number of transactions institutions (X5) decomposes into:

Number of transaction for Egyptian Institutions(X51).

Number of transactions for foreign Institutions(X52).

Number of transactions for Arab Institutions(X53).

Number of transaction for individuals (X6) decomposes into.

Number of transactions for Egyptian individuals (X61).

Number of transactions of foreign individuals (X62).

Number of transactions of Arab individuals (X63).

B. Dependent variable:

Capital market return which is equal to the change percentage of daily capital market value. 
Table 1. The descriptive statistics of the research variables

\begin{tabular}{|c|c|c|c|c|c|c|c|c|}
\hline Var & Mean & StDev & Min & Median & $\operatorname{Max}$ & Skew & Kurtosis & J. Bara \\
\hline $\mathrm{y}$ & 0.04 & 1.22 & -0.1 & 0.0 & 0.1 & -0.5 & 3.9 & 8.03 \\
\hline $\mathrm{X} 1$ & 43338871.0 & 42869151.0 & 6917400.0 & 35850754.0 & 877395853.0 & 10.7 & 170.0 & $1.44 \mathrm{E}+4 *$ \\
\hline $\mathrm{x} 11$ & 17367468.0 & 23913856.0 & 2592606.0 & 13573535.0 & 652507043.0 & 17.5 & 432.4 & $9.26 \mathrm{E}+4 *$ \\
\hline $\mathrm{X} 12$ & 19209564.0 & 22585261.0 & 968978.0 & 14835442.0 & 391752769.0 & 9.4 & 130.7 & $8.58 \mathrm{E}+3 *$ \\
\hline $\mathrm{X} 13$ & 6761839.0 & 14478817.0 & 465554.0 & 4889471.0 & 441428698.0 & 24.0 & 693.2 & $2.38 \mathrm{E}+5^{*}$ \\
\hline $\mathrm{X} 2$ & 180337578.0 & 88657234.0 & 35676738.0 & 159159282.0 & 731103628.0 & 1.3 & 2.2 & 5.50 \\
\hline $\mathrm{X} 21$ & 169124909.0 & 81909684.0 & 35251401.0 & 150979817.0 & 696804135.0 & 1.3 & 2.3 & 5.79 \\
\hline $\mathrm{X} 22$ & 1110058.0 & 1096736.0 & 6000.0 & 770322.0 & 10780769.0 & 2.7 & 12.9 & $9.73 \mathrm{E}+1 *$ \\
\hline $\mathrm{X} 23$ & 10102611.0 & 9318743.0 & 419337.0 & 7098185.0 & 72490761.0 & 2.7 & 9.9 & $6.26 \mathrm{E}+01$ \\
\hline $\mathrm{X} 3$ & 582125815.0 & 2106389268.0 & 27299497.0 & 356235521.0 & 39117543262.0 & 15.5 & 254.9 & $3.25 \mathrm{E}+4 *$ \\
\hline X31 & 225235629.0 & 1520648116.0 & 6711637.0 & 106155943.0 & 38993634672.0 & 21.7 & 503.1 & $1.26 \mathrm{E}+5^{*}$ \\
\hline $\mathrm{X} 32$ & 288805575.0 & 864480410.0 & 6233477.0 & 193507172.0 & 21856352563.0 & 18.8 & 407.7 & $8.25 \mathrm{E}+4 *$ \\
\hline X33 & 68084610.0 & 503366009.0 & 1397380.0 & 36086101.0 & 16913492930.0 & 31.8 & 1057.9 & $5.53 \mathrm{E}+5^{*}$ \\
\hline $\mathrm{X} 4$ & 840273714.0 & 561442948.0 & 111911547.0 & 690807407.0 & 4468987932.0 & 1.5 & 3.1 & $9.40 \mathrm{E}+00$ \\
\hline $\mathrm{X} 41$ & 785344769.0 & 528808715.0 & 106207540.0 & 643261661.0 & 4432854264.0 & 1.6 & 3.6 & $1.14 \mathrm{E}+1^{*}$ \\
\hline $\mathrm{X} 42$ & 6421915.0 & 8746334.0 & 92085.0 & 3712169.0 & 98827737.0 & 4.4 & 27.5 & $4.09 \mathrm{E}+02 *$ \\
\hline $\mathrm{X} 43$ & 48507031.0 & 48493949.0 & 1613066.0 & 35924117.0 & 727631450.0 & 5.7 & 60.4 & $1.86 \mathrm{E}+3 *$ \\
\hline $\mathrm{X} 5$ & 8764.2 & 3370.1 & 1383.0 & 8488.0 & 22365.0 & 0.5 & 0.4 & $6.27 \mathrm{E}-1 *$ \\
\hline X51 & 3281.8 & 1596.5 & 399.0 & 3048.0 & 13016.0 & 1.0 & 1.8 & 3.61 \\
\hline X52 & 4466.1 & 2158.6 & 214.0 & 4224.0 & 17368.0 & 1.0 & 2.2 & 4.25 \\
\hline X53 & 1016.2 & 550.0 & 108.0 & 923.0 & 3806.0 & 1.1 & 1.4 & 3.10 \\
\hline X6 & 57712.0 & 31967.0 & 11981.0 & 50483.0 & 183141.0 & 1.2 & 1.4 & 3.67 \\
\hline X61 & 56102.0 & 31078.0 & 11406.0 & 48965.0 & 178745.0 & 1.2 & 1.4 & 3.69 \\
\hline X62 & 191.1 & 152.2 & 13.0 & 152.0 & 1238.0 & 2.3 & 8.2 & $4.33 \mathrm{E}+1 *$ \\
\hline $\mathrm{X} 63$ & 1418.9 & 885.0 & 205.0 & 1209.0 & 5541.0 & 1.3 & 1.8 & 5.08 \\
\hline
\end{tabular}

*: means the corresponding variable doesn't follow the normal distribution.

The dependent variable (capital market return) showed normal distribution according to Jarque-Bera test and it could be state that there is no randomness in the data. While independent variables (Institutions and individuals) from X1 to X6 showed that all institutions traded volume, value and number of transactions were not normally distributed and all individuals traded volume, value and number of transactions were normally distributed, which indicate that the institutions were the main source of randomness in the Egyptian stock market.

The model was developed in three steps. First, performing lead lag structure approach is to obtain the optimum lag for the independent variable which has the maximum correlation with the dependent variable. Second, utilizing Garch model for its ability to capture volatility to the institution and individual trading (trading volume, trading value and number of transactions), decomposed into three investors categories (Foreign, Arabian and Egyptian) clustering in stock return data. Finally, retry utilizing the models for each year to identify variation for the effect of independent variables (Institutions and individuals traded volume, value and number of transactions for Foreigners, Arab, and Egyptian) on capital market return volatility.

This study hypothesizes that the Egyptian Stock Exchange capital market return volatile due to the movements of trading volume, value and number of transactions which took place by the actions of institutions and individuals for Foreigners, Arab and Egyptian, and this volatility might vary across time during five years period from January 1st 2009 to December 312013 by employing ARCH /GARCH model.

The models are as follows:

$$
\begin{gathered}
Y=f\{X 1, X 2, X 3, X 4, X 5, X 6\} \\
Y=f\{X 11, X 12, X 13, X 21, X 22, X 23, X 31, X 32, X 33, X 41, X 42, X 43, X 51, X 52, X 53, X 61, X 62, X 63\}
\end{gathered}
$$

The derived mathematical multiple regression of the above models is:

$$
\begin{gathered}
Y t=\alpha+\beta 1 X(t-g)+\beta 2 X 2(t-g)+\beta 3 X 3(t-g)+\beta 4 X 4(t-g)+\beta 5 X 5(t-g)+\beta 6 X 6(t-g)+\varepsilon t \\
Y t=\alpha+\beta 1 X 11(t-g)+\beta 2 X 12(t-g)+\beta 3 X 13(t-g)+\beta 4 X 21(t-g)+\beta 5 X 22(t-g)+\beta 6 X 23(t-g)+\beta 7 X 31(t g)+\beta 8 X 32 \\
(t-g)+\beta 9 X 33(t-g)+\beta 10 X 41(t-g)+\beta 11 X 42(t-g)+\beta 12 X 43(t-g)+\beta 13 X 51(t-g)+\beta 14 X 52(t-g)+\beta 15 X 53(t-g)+ \\
\beta 16 X 61(t-g)+\beta 17 X 62(t-g)+\beta 18 X 63(t-g)+\varepsilon t
\end{gathered}
$$


In equations ( 3 and 4$), \mathrm{Y}$ representing capital market volatility, $\alpha$ is constant, $\beta$ are the coefficients, $\mathrm{X}$ are representing independent variables, $\mathrm{t}$ is the daily date, $\mathrm{g}$ is the lead lag structure value $\& \varepsilon$ is the error term. In the light of literature review, the coefficient of variables; X's, are expected to be positive.

\section{Results}

The influence of trading volume, value and number of transactions for institutions and individuals of Foreigners, Arab and Egyptian variables on the capital market returns was estimated utilizing both OLS and ARCH/GARCH estimation models respectively.

Table 2. The estimation of the effect of influence of trading volume, value and number of transactions for institutions and individuals on the capital market return for the period from January 1st 2009 to December 31 2013 Dependent Variable: Y (Daily Capital Market Return)

ARCH test:

\begin{tabular}{lcccc}
\hline F-Statistics & 115.2830 & Probability & \multicolumn{2}{c}{0.0000} \\
Obs*R squared & 105.2238 & Probability & 0.0000 \\
\hline Variables & Coefficient & Std. Error & z-Statistic & Prob. \\
\hline C & -0.005652 & 0.001561 & -3.620597 & 0.0003 \\
X1(-3) & $3.16 \mathrm{E}-13$ & $2.37 \mathrm{E}-13$ & 1.335238 & 0.0818 \\
X4 (-1) & $1.50 \mathrm{E}-11$ & $5.79 \mathrm{E}-12$ & 2.594420 & 0.0095 \\
X5 (0) & $3.81 \mathrm{E} 07$ & $1.34 \mathrm{E}-07$ & 2.847158 & 0.0044 \\
\hline Variance Equation & & & \\
\hline $\mathrm{C}$ & 0.000225 & $7.69 \mathrm{E}-06$ & 29.18651 & 0.0000 \\
ARCH(1) & 0.234921 & 0.033979 & 6.913689 & 0.0000 \\
\hline R-squared & 0.016341 & Mean dependent var & & 0.000458 \\
Adjusted R-squared & 0.012180 & S.D. dependent var & & 0.017376 \\
S.E. of regression & 0.017270 & Akaike info criterion & & -5.350282 \\
Sum squared resid & 0.352529 & Schwarz criterion & & -5.324625 \\
Log Likelihood & 3184.067 & F-Statistics & 3.927103 \\
Durbin-Watson stat & 1.673037 & Prob(F-Statistics) & & 0.001551 \\
\hline
\end{tabular}

The model gave an explanation of $1.6 \%$ of the variation in capital market return which means that there were 98.4\% explained by other variables and the calculated coefficients of X4 trading value of individuals and X5 number of transactions of institutions were positive and significant at $5 \%$.

Table 3. The estimation of the effect of Foreigners, Arab and Egyptian institutions and individuals for trading volume, value and number of transactions on the capital market return for the period from January 1st 2009 to December 312013 Dependent Variable: Y (Daily Capital Market Return)

ARCH test:

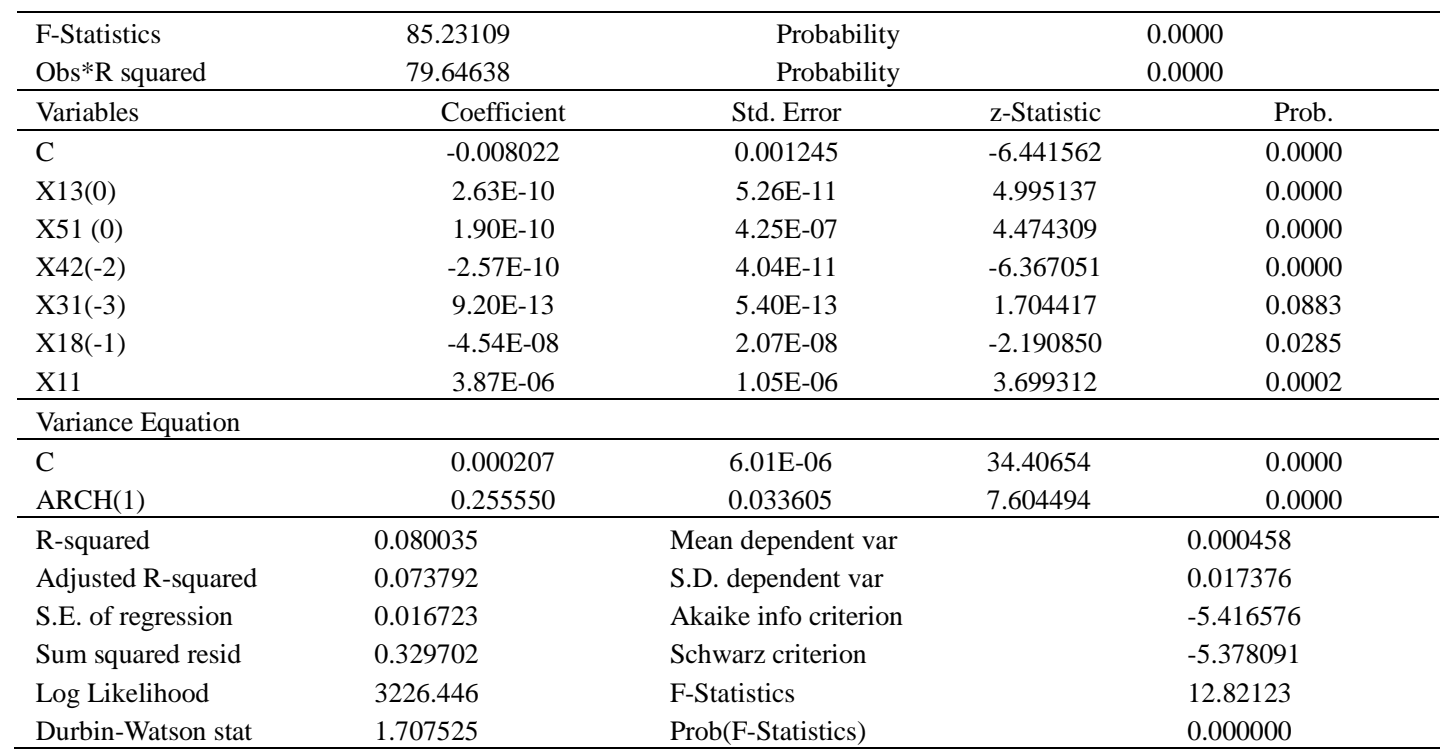


The model gave an explanation of $8 \%$ of the variation in capital market return which means that there were $92 \%$ explained by other variables and The calculated coefficients of X13 trading volume for Arab institutions, X51 number of transaction for Egyptian Institutions X42 trading value for foreign individuals, X61 number of transactions for Egyptian individuals X53 number of transactions for Arab Institutions were positive and significant at $5 \%$.

Table 2 and 3 which represent the whole period didn't show which trading activities or investor categories have the core effect on capital market return volatility and this might return to nature of the research period which include consequences of world-wide financial crisis and 25th Egyptian revolution and its consequences, so we were gone to divide the whole period into five periods trying to discover the differentiation of the effect and the core of it and how it was changing across the five years by applying the two previous models as follows:

Table 4. The estimation of the effect of influence of trading volume, value and number of transactions for institutions and individuals on the capital market return for the period from January 1st 2009 to December 31 2009 Dependent Variable: Y (Daily Capital Market Return)

\begin{tabular}{lllll}
\hline Variables & Coefficient & Std. Error & z-Statistic & Prob. \\
\hline $\mathrm{C}$ & -0.0013413 & 0.002535 & -5.290116 & 0.0000 \\
$\mathrm{X} 1(0)$ & $4.01 \mathrm{E}-11$ & $1.19 \mathrm{E}-11$ & 3.374275 & 0.0000 \\
$\mathrm{X} 4(0)$ & $4.81 \mathrm{E}-12$ & $2.46 \mathrm{E}-12$ & 1.950990 & 0.0511 \\
\hline Variance Equation & & & \\
\hline $\mathrm{C}$ & 0.000263 & $2.30 \mathrm{E}-05$ & 11.47239 & 0.0000 \\
RESID(-1)^2 & 0.171429 & 0.086417 & 1.983731 & 0.0473 \\
\hline R-squared & 0.097782 & Mean dependent var & 0.001431 \\
Adjusted R-squared & 0.090447 & S.D. dependent var & & 0.021121 \\
S.E. of regression & 0.020143 & Akaike info criterion & & -4.901899 \\
Sum squared resid & 0.099814 & Schwarz criterion & & -4.831267 \\
Log Likelihood & 615.2864 & F-Statistics & & -4.873468 \\
Durbin-Watson stat & 1.791636 & & \\
\hline
\end{tabular}

The model gave an explanation of $9.8 \%$ of the variation in capital market return which means that there were 91.2\% explained by other variables and the calculated coefficients of X1 trading volume for institutions and X4 trading value of individuals were positive and significant at $5 \%$.

Table 5. The estimation of the effect of Foreigners, Arab and Egyptian institutions and individuals for trading volume, value and number of transactions on the capital market return for the period from January 1st 2009 to December 312009 Dependent Variable: Y (Daily Capital Market Return)

\begin{tabular}{lllll}
\hline Variables & Coefficient & Std. Error & z-Statistic & Prob. \\
C & -0.007006 & 0.004971 & -1.409404 & 0.1600 \\
X11(0) & $5.17 \mathrm{E}-11$ & $2.32 \mathrm{E}-11$ & 2.226514 & 0.0269 \\
X43(-1) & $-1.59 \mathrm{E}-10$ & $3.99 \mathrm{E}-11$ & -3.988348 & 0.0001 \\
X41(0) & $9.00 \mathrm{E}-12$ & $3.47 \mathrm{E}-12$ & 2.5966309 & 0.0100 \\
X32(-1) & $1.23 \mathrm{E}-11$ & $5.18 \mathrm{E}-12$ & 2.372284 & 0.0185 \\
X15(-3) & $6.23 \mathrm{E}-11$ & $2.99 \mathrm{E}-11$ & 2.085391 & 0.0381 \\
X23(-5) & $-1.60 \mathrm{E}-06$ & $9.04 \mathrm{E}-07$ & -1.771460 & 0.0778 \\
\hline R-squared & 0.191700 & Mean dependent var & 0.001430 \\
Adjusted R-squared & 0.171236 & S.D. dependent var & 0.021249 \\
S.E. of regression & 0.019344 & Akaike info criterion & -5.024557 \\
\hline Sum squared resid & 0.088687 & Schwarz criterion & -4.924229 \\
Log Likelihood & 619.9960 & Hannan-Quinn criter & -4.984150 \\
F-Statistics & 9.367966 & Durbin-Watson stat & 1.887186 \\
Prob(F-static) & 0.000000 & & \\
\hline
\end{tabular}

The model gives an explanation of $19.2 \%$ of the variation in capital market return which means that there were 80.8\% explained by other variables and The calculated coefficients of X11 trading volume for Egyptian 
institutions, X41 trading value for Egyptian individuals, X32 trading value for foreign institutions X11 trading volume for Egyptian institutions were positive expect X43 trading value for Arab individuals were negative and significant at $5 \%$ which contradict with all the previous studies and that indicate that not all investor categories within the Egyptian market were moving in the same direction and confirm random status of such market due to the dramatic change of investor sentiment which have negative effect on stock market return volatility Xindan $\&$ Bing (2008).

Table 6. The estimation of the effect of influence of trading volume, value and number of transactions for institutions and individuals on the capital market return for the period from January 1 st 2010 to December 31 2010 Dependent Variable: Y (Daily Capital Market Return)

\begin{tabular}{lllll}
\hline Variables & Coefficient & Std. Error & z-Statistic & Prob. \\
\hline $\mathrm{C}$ & -0.006651 & 0.002678 & -2.483802 & 0.0130 \\
$\mathrm{X} 3(0)$ & $3.49 \mathrm{E}-12$ & $3.30 \mathrm{E}-12$ & 1.055452 & 0.0491 \\
$\mathrm{X} 4(0)$ & $4.90 \mathrm{E}-12$ & $2.66 \mathrm{E}-12$ & 1.844105 & 0.0465 \\
\hline Variance Equation & & & \\
\hline $\mathrm{C}$ & 0.000138 & $1.57 \mathrm{E}-05$ & 8.781654 & 0.0000 \\
$\mathrm{RESID}(-1)^{\wedge} 2$ & 0.171429 & 0.102787 & 1.667808 & 0.0954 \\
\hline R-squared & 0.052953 & Mean dependent var & 0.000657 \\
Adjusted R-squared & 0.045190 & S.D. dependent var & & 0.013408 \\
S.E. of regression & 0.013102 & Akaike info criterion & & -5.850094 \\
Sum squared resid & 0.041883 & Schwarz criterion & & -5.779054 \\
Log Likelihood & 727.4866 & F-Statistics & & -5.821492 \\
Durbin-Watson stat & 1.985710 & & \\
\hline
\end{tabular}

The model gave an explanation of $5.3 \%$ of the variation in capital market return which means that there were $94.7 \%$ explained by other variables and the calculated coefficients of X3 trading value for institutions and X4 trading value of individuals were positive and significant at $5 \%$.

Table 7. The estimation of the effect of Foreigners, Arab and Egyptian institutions and individuals for trading volume, value and number of transactions on the capital market return for the period from January 1 st 2010 to December 312010 Dependent Variable: Y (Daily Capital Market Return)

\begin{tabular}{|c|c|c|c|c|}
\hline Variables & Coefficient & Std. Error & z-Statistic & Prob. \\
\hline $\mathrm{C}$ & -0.005036 & 0.002544 & -1.979968 & 0.0477 \\
\hline $\mathrm{X} 32(0)$ & $4.01 \mathrm{E}-11$ & $4.68 \mathrm{E}-12$ & 1.685456 & 0.0919 \\
\hline$X 42(-9)$ & $-3.19 \mathrm{E}-10$ & $5.93 \mathrm{E}-11$ & -5.384748 & 0.0000 \\
\hline X63(0) & $4.52 \mathrm{E}-06$ & $1.62 \mathrm{E}-06$ & 2.794636 & 0.0052 \\
\hline $\mathrm{X} 43(-4)$ & $-3.77 \mathrm{E}-11$ & $1.47 \mathrm{E}-11$ & -2.558945 & 0.0105 \\
\hline $\mathrm{X} 33(0)$ & $6.13 \mathrm{E}-12$ & $9.43 \mathrm{E}-12$ & 1.650153 & 0.0516 \\
\hline \multicolumn{5}{|l|}{ Variance Equation } \\
\hline $\mathrm{C}$ & 0.000119 & $1.40 \mathrm{E}-05$ & 8.492148 & 0.0000 \\
\hline $\operatorname{RESID}(-1)^{\wedge} 2$ & 0.171429 & 0.077809 & 2.203187 & 0.0276 \\
\hline R-squared & 0.097782 & \multicolumn{2}{|c|}{ Mean dependent var } & 0.000657 \\
\hline Adjusted R-squared & 0.116585 & \multicolumn{2}{|c|}{ S.D. dependent var } & 0.013408 \\
\hline S.E. of regression & 0.012602 & \multicolumn{2}{|c|}{ Akaike info criterion } & -5.928241 \\
\hline Sum squared resid & 0.038275 & \multicolumn{2}{|c|}{ Schwarz criterion } & -5.814577 \\
\hline Log Likelihood & 740.1378 & \multicolumn{2}{|l|}{ F-Statistics } & -5.882479 \\
\hline Durbin-Watson stat & 2.097270 & & & \\
\hline
\end{tabular}

The model gives an explanation of $9.8 \%$ of the variation in capital market return which means that there were 91.2\% explained by other variables and The calculated coefficients of X42 trading value for Foreigners individuals, X43 trading value for Arab individuals, were negative expect X63 number of transactions of Arab individuals, was positive and significant at $5 \%$ which contradict with all the previous studies and that indicate that not all investor categories within the Egyptian market were not moving in the same direction and confirm random status of such market due to the dramatic change of investor sentiment which have negative effect on 
stock market return volatility (Xindan \& Bing, 2008).

Table 8. The estimation of the effect of influence of trading volume, value and number of transactions for institutions and individuals on the capital market return for the period from January 1st 2011 to December 31 2011 Dependent Variable: Y (Daily Capital Market Return)

\begin{tabular}{lllll}
\hline Variables & Coefficient & Std. Error & z-Statistic & Prob. \\
\hline $\mathrm{C}$ & 0.001910 & 0.003005 & 1.483802 & 0.0525 \\
$\mathrm{X} 3(-7)$ & $-1.72 \mathrm{E}-12$ & $2.49 \mathrm{E}-11$ & -0.690611 & 0.4898 \\
$\mathrm{X} 4(-7)$ & $-2.78 \mathrm{E}-12$ & $2.09 \mathrm{E}-12$ & -1.327757 & 0.0843 \\
\hline Variance Equation & & & \\
\hline $\mathrm{C}$ & 0.000186 & $3.49 \mathrm{E}-05$ & 5.328257 & 0.0000 \\
RESID(-1)^2 & 0.480564 & 0.184036 & 2.611251 & 0.0090 \\
\hline R-squared & 0.022902 & Mean dependent var & -0.003084 \\
Adjusted R-squared & 0.013323 & S.D. dependent var & & 0.019361 \\
S.E. of regression & 0.019232 & Akaike info criterion & & -5.309106 \\
Sum squared resid & 0.041883 & Schwarz criterion & -5.779054 \\
Log Likelihood & 555.4925 & Hannan-Quinn criter & & -5.270042 \\
Durbin-Watson stat & 1.467698 & \multicolumn{5}{l}{} \\
\hline
\end{tabular}

The model gave an explanation of $2.3 \%$ of the variation in capital market return which means that there were 97.7\% explained by other variables and the calculated coefficients of X3 trading value for institutions was negative and significant at $5 \%$, which contradict with all the previous studies and this might indicate market decline during 25th Egyptian revolution and rising irrational behavior that might lead to the scratch of financial markets (Baur et al., 1996).

Table 9. The estimation of the effect of Foreigners, Arab and Egyptian institutions and individuals for trading volume, value and number of transactions on the capital market return for the period from January 1 st 2011 to December 312011 Dependent Variable: Y (Daily Capital Market Return)

\begin{tabular}{lllll}
\hline Variables & Coefficient & Std. Error & Z-Statistic & Prob. \\
\hline $\mathrm{C}$ & -0.001503 & 0.003113 & 0.482791 & 0.6292 \\
X18(-7) & $-1.06 \mathrm{E}-07$ & $6.16 \mathrm{E}-08$ & -1.723653 & 0.0848 \\
X13(-7) & $-5.78 \mathrm{E}-12$ & $4.25 \mathrm{E}-12$ & -1.359161 & 0.0741 \\
X22(0) & $2.24 \mathrm{E}-09$ & $1.31 \mathrm{E}-09$ & 1.702887 & 0.0886 \\
\hline Variance Equation & & & \\
\hline C & 0.000185 & $1.40 \mathrm{E}-05$ & 8.492148 & 0.0000 \\
RESID(-1)^2 & 0.444798 & 0.126124 & 3.526684 & 0.0004 \\
\hline R-squared & 0.044171 & Mean dependent var & & -0.003084 \\
Adjusted R-squared & 0.030045 & S.D. dependent var & & 0.019361 \\
S.E. of regression & 0.019068 & Akaike info criterion & & -5.290445 \\
Sum squared resid & 0.073807 & Schwarz criterion & & -5.193844 \\
Log Likelihood & 553.5611 & Hannan-Quinn criter & & -5.251381 \\
Durbin-Watson stat & 1.525633 & & \\
\hline
\end{tabular}

The model gives an explanation of $4.4 \%$ of the variation in capital market return which means that there were $95.6 \%$ explained by other variables and the calculated coefficients were not significant at $5 \%$ and this might return to the negative influence of 25th Egyptian revolution. 
Table 10. The estimation of the effect of influence of trading volume, value and number of transactions for institutions and individuals on the capital market return for the period from January 1st 2012 to December 31 2012 Dependent Variable: Y (Daily Capital Market Return)

\begin{tabular}{lllll}
\hline Variables & Coefficient & Std. Error & z-Statistic & Prob. \\
$\mathrm{C}$ & -0.009632 & 0.002675 & -3.601198 & 0.0003 \\
$\mathrm{X} 5(0)$ & $1.00 \mathrm{E}-06$ & $4.80 \mathrm{E}-07$ & 2.091746 & 0.0365 \\
$\mathrm{X} 3(0)$ & $-1.22 \mathrm{E}-12$ & $8.84 \mathrm{E}-12$ & -1.137922 & 0.0890 \\
$\mathrm{X} 1(0)$ & $7.73 \mathrm{E}-11$ & $6.46 \mathrm{E}-11$ & 1.967245 & 0.0231 \\
\hline Variance Equation & \multicolumn{5}{l}{} \\
\hline $\mathrm{C}$ & 0.000207 & $1.14 \mathrm{E}-05$ & 18.19832 & 0.0000 \\
RESID(-1)^2 & 0.171429 & 0.050231 & 3.412799 & 0.0006 \\
\hline R-squared & 0.077597 & Mean dependent var & 0.001844 \\
Adjusted R-squared & 0.066115 & S.D. dependent var & 0.018237 \\
S.E. of regression & 0.017624 & Akaike info criterion & -5.195597 \\
Sum squared resid & 0.074857 & Schwarz criterion & -5.109852 \\
Log Likelihood & 642.4606 & Hannan-Quinn criter & -5.161068 \\
Durbin-Watson stat & 1.717517 & \multicolumn{5}{l}{} \\
\hline
\end{tabular}

The model gave an explanation of $7.8 \%$ of the variation in capital market return which means that there were 92.2\% explained by other variables and the calculated coefficients of X5 number of transactions institutions and $\mathrm{X} 3$ trading value of institutions were positive and significant at $5 \%$.

Table 11. The estimation of the effect of Foreigners, Arab and Egyptian institutions and individuals for trading volume, value and number of transactions on the capital market return for the period from January 1 st 2012 to December 312012 Dependent Variable: Y (Daily Capital Market Return)

\begin{tabular}{lllll}
\hline variables & Coefficient & Std. Error & Z-Statistic & Prob. \\
$\mathrm{C}$ & -0.007611 & 0.003046 & -2.498526 & 0.0125 \\
$\mathrm{X} 63(0)$ & $1.13 \mathrm{E}-05$ & $4.18 \mathrm{E}-06$ & 2.706555 & 0.0068 \\
$\mathrm{X} 42(-2)$ & $-7.20 \mathrm{E}-11$ & $1.88 \mathrm{E}-11$ & -3.837199 & 0.0001 \\
$\mathrm{X} 43(0)$ & $-2.42 \mathrm{E}-11$ & $7.61 \mathrm{E}-12$ & -3.178172 & 0.0015 \\
$\mathrm{X} 51(0)$ & $3.09 \mathrm{E}-06$ & $1.28 \mathrm{E}-06$ & 2.423663 & 0.0154 \\
$\mathrm{X} 13(0)$ & $2.60 \mathrm{E}-10$ & $1.81 \mathrm{E}-10$ & 1.437921 & 0.0905 \\
\hline Variance Equation & \multicolumn{5}{|}{} \\
\hline $\mathrm{C}$ & 0.000240 & $1.61 \mathrm{E}-05$ & 0.0000 \\
RESID(-1)^2 & 0.144503 & 0.059384 & 2.433345 & 0.0150 \\
\hline R-squared & 0.167857 & Mean dependent var & 0.001844 \\
Adjusted R-squared & 0.150448 & S.D. dependent var & 0.018237 \\
S.E. of regression & 0.016810 & Akaike info criterion & -5.308051 \\
Sum squared resid & 0.067532 & Schwarz criterion & -5.193724 \\
Log Likelihood & 658.2362 & Hannan-Quinn criter & \\
Durbin-Watson stat & 1.719737 & & \\
\hline
\end{tabular}

The model gives an explanation of $16.8 \%$ of the variation in capital market return which means that there were 83.2\% explained by other variables and The calculated coefficients of X42 trading value for Foreigners individuals, and X43 trading value for Arab individuals, were negative expect X63 number of transactions of Arab individuals and X51 number of transaction for Egyptian Institutions were positive and significant at 5\% which contradict with all the previous studies and that indicate that not all investor categories within the Egyptian market were not moving in the same direction and confirm random status of such market due to the rising irrational behavior that might lead to the scratch of financial markets Baur et al. (1996). 
Table 12. The estimation of the effect of influence of trading volume, value and number of transactions for institutions and individuals on the capital market return for the period from January 1st 2013 to December 31 2013 Dependent Variable: Y (Daily Capital Market Return)

\begin{tabular}{lllll}
\hline Variables & Coefficient & Std. Error & z-Statistic & Prob. \\
$\mathrm{C}$ & 0.002412 & 0.002315 & 1.042080 & 0.2974 \\
$\mathrm{X} 4(0)$ & $1.08 \mathrm{E}-11$ & $3.43 \mathrm{E}-12$ & 3.163672 & 0.0016 \\
$\mathrm{X} 5(-5)$ & $-9.15 \mathrm{E}-07$ & $3.03 \mathrm{E}-07$ & -3.020234 & 0.0025 \\
$\mathrm{X} 1(-4)$ & $-2.92 \mathrm{E}-11$ & $1.92 \mathrm{E}-11$ & -1.523414 & 0.0928 \\
\hline Variance Equation & \multicolumn{5}{|}{} \\
\hline $\mathrm{C}$ & 0.000106 & $6.71 \mathrm{E}-06$ & 15.75087 & 0.0000 \\
RESID(-1)^2 & 0.171429 & 0.060919 & 0.0049 \\
\hline R-squared & 0.078074 & Mean dependent var & 0.000978 \\
Adjusted R-squared & 0.066502 & S.D. dependent var & 0.013237 \\
S.E. of regression & 0.012790 & Akaike info criterion & -5.845951 \\
Sum squared resid & 0.039094 & Schwarz criterion & -5.759703 \\
Log Likelihood & 716.2830 & Hannan-Quinn criter & -5.811211 \\
Durbin-Watson stat & 1.882579 & \multicolumn{5}{l}{} \\
\hline
\end{tabular}

The model gives an explanation of $7.8 \%$ of the variation in capital market return which means that there were 92.2\% explained by other variables and The calculated coefficients of X4 trading value for individuals, was negative and X5 number of transactions for institutions, was positive and significant at 5\% which contradict with all the previous studies and that indicate that not all investor categories within the Egyptian market was not moving in the same direction and confirm random status of such market due to the dramatic change of investor sentiment which have negative effect on stock market return volatility (Xindan \& Bing, 2008).

Table 13. The estimation of the effect of Foreigners, Arab and Egyptian institutions and individuals for trading volume, value and number of transactions on the capital market return for the period from January 1st 2013 to December 312013 Dependent Variable: Y (Daily Capital Market Return)

\begin{tabular}{lllll}
\hline Variables & Coefficient & Std. Error & z-Statistic & Prob. \\
$\mathrm{C}$ & 0.000956 & 0.002868 & 0.333475 & 0.7388 \\
X51(0) & $1.13 \mathrm{E}-05$ & $4.18 \mathrm{E}-06$ & 2.706555 & 0.0068 \\
X53(-6) & $3.34 \mathrm{E}-06$ & $8.94 \mathrm{E}-07$ & 3.730720 & 0.0002 \\
X12(-4) & $-6.84 \mathrm{E}-11$ & $5.99 \mathrm{E}-11$ & -1.418867 & 0.0925 \\
X33(-2) & $-4.65 \mathrm{E}-11$ & $1.32 \mathrm{E}-11$ & -3.512622 & 0.0004 \\
\hline Variance Equation & & & \\
\hline $\mathrm{C}$ & 0.000240 & $1.61 \mathrm{E}-05$ & 14.86807 & 0.0000 \\
RESID(-1)^2 & 0.144503 & 0.059384 & 2.433345 & 0.0150 \\
\hline R-squared & 0.130329 & Mean dependent var & 0.000978 \\
Adjusted R-squared & 0.115713 & S.D. dependent var & \\
S.E. of regression & 0.012448 & Akaike info criterion & \\
Sum squared resid & 0.036878 & Schwarz criterion & -5.936734 \\
Log Likelihood & 728.3131 & Hannan-Quinn criter & \\
Durbin-Watson stat & 1.895334 & & \\
\hline
\end{tabular}

The model gives an explanation of $13 \%$ of the variation in capital market return which means that there were $87 \%$ explained by other variables and The calculated coefficients of X51 number of transactions for Egyptian institutions, and X53 number of transactions for Arab institutions, were positive expect X33 trading value for Arab institutions was negative and significant at 5\% which contradict with all the previous studies and that indicate that not all investor categories within the Egyptian market were not moving in the same direction and confirm random status of such market due to the dramatic change of investor sentiment which have negative effect on stock market return volatility (Xindan \& Bing, 2008).

\section{Conclusion}

In this paper we tried to estimate the effect of trading volume, value, number of transactions and investor 
categories of institutions, individuals for Egyptians, Foreigners and Arab on capital market return volatility for by utilizing two models the first measuring the effect of trading volume, value, number of transactions on capital market volatility and the second measuring the effect of investor categories of institutions, individuals for Egyptians, Foreigners and Arab on capital market return volatility the period from January 1st 2009 to December 312013 and gave a weak estimation which might refer to the crisis and its consequences included within the period, so we divided the period into five periods and the results showed weak estimation R2 for all periods. This isn't confirm the role of macroeconomic variables interrelation between stock markets in estimating domestic market return volatility in advanced and emerging markets which were consistent with many previous studies such as Mala (2007) Fiji's stock market, Mele (2008) London stock market, Rao (2008) Gulf stock markets, Aliyu (2011) Nigeria and Ghana stock markets, Chiou (2011) Tokyo, London, and New York stock markets, Beetsma and Giuliodori (2012) U.S. stock markets, because macro-economic variables were depending on low frequency data, while high frequency data which we depended on reveals more about the volatility properties Daly (2008).

Consistent with Chiou (1988), the findings of GARCH model indicated that volatility persistence is less than unity (variance equation showed that $\operatorname{Arch}(1)$ or $\left.\operatorname{Garch}(1)+\operatorname{Resid}(-1)^{\wedge} 2<1\right)$ which means that shocks effect on capital market volatility were decreasing across time and this was a good sign of attracting investors toward investing in Egyptian stock market than many other emerging markets

Besides this, we remarked that the effect of independent variable increase when the dramatic financial and political events and its consequences tend towards stability and vice versa.

Finally, the results confirm the main source of volatility which indicates the high speculations within the Egyptian market was Foreigners and the traded value (Institutions and individuals for all categories Foreigners, Arab and Egyptian) are the main source of influencing the capital market return volatility.

\section{References}

Adaoglu, C., \& Katircioglu, S. T. (2013). Foreign investor flows and "blue chip" stock returns. International Journal of Emerging Markets, 8(2), 170-181. http://dx.doi.org/10.1108/17468801311307037

Aliyu, S. U. R. (2011). Does inflation has an effect on Stock Returns and Volatility? Evidence from Nigeria and Ghana. International Conference on Economics and Finance Research IPEDR, 4.

Bagchi, D. (2012). Cross-sectional analysis of emerging market volatility index (India VIX) with portfolio $\begin{array}{llll}\text { returns. International Journal of Emerging } & \text { Markets, }\end{array}$ http://dx.doi.org/10.1108/17468801211264306

Baur, M. N., Socorr, Q., \& Eric, S. (1996). The 1986-88 Stock Market: Investor Sentiment or Fundamentals? Managerial and Decision Economics, 17, 319-329.

Beetsma, R., \& Giuliodori, M. (2012). The Changing Macroeconomic Response to Stock Market Volatility Shocks. Department of Economics, University of Amsterdam, p. 1.

Chiou, I. (2011). The volatility transmission of stock returns across Asia, Europe, and North America. Managerial Finance, 37(5), 442-450. http://dx.doi.org/10.1108/ 03074351111126924

Daly, K. (2008). Financial volatility: Issues and measuring techniques. Physica A, 387, 2377-2393. http://dx.doi.org/10.1016/j.physa.2008.01.009

Girard, E., \& Biswas, R. (2007). Trading Volume and Market Volatility: Developed versus Emerging Stock Markets. The Financial Review, 42, 429-459. http://dx.doi.org/10.1111/j.1540-6288.2007.00178.x

Girard, E., \& Omran, M. (2009). On the relationship between trading volume and stock price volatility in CASE. $\begin{array}{llll}\text { International Journal of } & \text { Managerial }\end{array}$ http://dx.doi.org/10.1108/17439130910932369.

Huang, R. D., \& Masulis, R. W. (2003). Trading activity and stock price volatility: Evidence from the London $\begin{array}{lllll}\text { Stock Exchange. Journal of Empirical } & \text { Finance, } & \text { 10(3), }\end{array}$ http://dx.doi.org/10.1016/S0927-5398(02)00048-8

Kaniel, R., Liu, S., Saar, G., \& Titman, S. (2012). Individual investor trading and return patterns around earnings announcements. Journal of Finance, 67, 639-680. http://dx.doi.org/10.1111/j.1540-6261.2012.01727.x.

Koutmos, G. (2014). Positive feedback trading: A review. Review of Behavioral Finance, 6(2), 155-162. http://dx.doi.org/10.1108/RBF-08-2014-0043

Kyröläinen, P. (2009). Day trading and stock price volatility. Journal of Economic Finance, 32, 75-89. 
http://dx.doi.org/10.1007/s12197-007-9006-2

Lan, L., Chaoqun, M., \& Jing, C. (2014). Price volatility, Trading Volume, and Market Depth: Evidence from Chinese Stock Index Futures Markets. Strategy in emerging markets: Management, finance and sustainable development, pp. 541-547.

Mala, R., \& Reddy, M. (2007). Measuring Stock Market Volatility in an Emerging Economy. International Research Journal of Finance and Economics, (8).

Mele, A. (2008). Macroeconomic Determinants of Stock Market Volatility and Volatility Risk-Premiums. London School of Economics, pp. 1-5.

Rao, A. (2008). Analysis of volatility persistence in Middle East emerging equity markets. Studies in Economics and Finance, 25(2), 93-111. http://dx.doi.org/10.1108/ 10867370810879429

Tauchen, G., \& Pitts, M. (1983). The price variability-volume relationship on speculative markets. Econometrica, 51, 485-505. http://dx.doi.org/10.2307/1912002

Tayde, M., \& Rao, S. V. D. N. (2012). Do foreign institutional investors (FIIs) exhibit herdings and positive feedback trading in Indian stock markets? International Finance Review, 12, 169-185. http://dx.doi.org/10.1108/S1569-3767(2011)0000012009

Tiaojun, X., \& Xiaoli, W. (2007). Manipulation, stockpricevolatility and trading volume in Chinese stock markets: An empirical evidence. International Conference on Management Innovation, 1 \&2, 572-579

Tomas, H. (2014). Stock Prices Volatility and Trading Volume: Evidence from Selected World Financial Companies'Shares. Proceedings of the 14th international conference on finance and banking, pp. 106-114.

Ulku, N., \& Weber, E. (2013). Identifying the interaction between stock market returns and trading flows of investor types: Looking into the day using daily data. Journal of Banking \& Finance, 37(8), 2733-2749. http://dx.doi.org/10.1016/j.jbankfin.2013.03.021

Wang, J. (1994), A model of competitive trading volume. Journal of Political Economy, 102, 127-168. http://dx.doi.org/10.1086/261924.

Wei, L., \& Steven Shuye, W. (2010). Daily institutional trades and stock price volatility in a retail investor dominated emerging market. Journal of Financial Markets, 13(4), 448-474.

Wen-I, C., Hsiang-His, L., \& Susmel, R. (2012). The bivariate GARCH approach to investigating the relation between stock returns, trading volume, and return volatility. Global Finance Journal, 23(1), 1-15.

Xindan, L., \& Bing, Z. (2008). Stock market behavior and investor sentiment: Evidence from China. Front. Bus. Res., 2(2), 277-282. http://dx.doi.org/10.1007/s11782-008-0016-5

\section{Copyrights}

Copyright for this article is retained by the author(s), with first publication rights granted to the journal.

This is an open-access article distributed under the terms and conditions of the Creative Commons Attribution license (http://creativecommons.org/licenses/by/3.0/). 